\title{
Inclusion and Representation: The Settlement of Property Claims of the Dispossessed in the Aftermath of an Armed Conflict
}

\author{
Tamar Megiddo* \& Eyal Benvenisti**
}

This Article examines the authority of states to settle individual private property claims in post-conflict negotiations towards settlement. We analyze this question by exploring the limits of states' authority to take or limit private property rights for the public good. We argue that this authority rests on two cumulative justifications: the inclusion of the property owners among the public that stands to benefit from the public good, and their representation by the government that decides on the taking of the property. In post-conflict settlement, the negotiating states may redistribute both private property and the public good between and within their respective communities. Their authority to redistribute continues to rests on the same justifications of inclusion and representation. Hence, their authority extends only to the redistribution of property of owners who are members of the respective communities that negotiate the agreement, and who are represented by a negotiating government.

* Post-Doctoral Fellow, Minerva Center for the Rule of Law Under Extreme Conditions, University of Haifa. The research was conducted under the auspices of the Minerva Center for the Rule of Law under Extreme Conditions, Faculty of Law and Department of Geography and Environmental Studies, University of Haifa.

** Whewell Professor of International Law, University of Cambridge, CC Ng Fellow, Jesus College, Cambridge, Visiting Professor, The Hebrew University of Jerusalem.

The authors thank Hanoch Dagan, Yaël Ronen and participants of the Historical Justice in the Context of the Israeli-Palestinian Conflict Conference at Tel Aviv University. Cite as: Tamar Megiddo \& Eyal Benvenisti, Inclusion and Representation: The Settlement of Property Claims of the Dispossessed in the Aftermath of an Armed Conflict, 21 TheORETICAL InQuiries L. 397 (2020). 


\section{INTRODUCTION}

Imagine an intense international armed conflict which has taken a toll on the civilian populations of one or all states involved, causing many to flee their homes en masse and relocate elsewhere, temporarily or permanently. Others are prevented from using their property that is situated beyond enemy lines. With a resolution of the conflict eluding the parties, the property left behind by the refugees has become the home of others. With or without acquiring valid title or governmental approval, oblivious or aware of the identity of the original owners, these new residents have built a new life and a new community on the ruins of the community displaced. The new residents, or their predecessors, may have been refugees themselves, expelled from other regions. They, or their parents, might have been sent by their government to populate the deserted neighborhood or village given immediate needs or due to scarce resources, or even with the intention to prevent the return of the former inhabitants.

The conflicting claims of these individuals and communities have attracted wide scholarly attention. ${ }^{1}$ Considerations of justice and human rights have informed the debate concerning the respective rights and legitimate expectations of both dispossessed owners and new residents. ${ }^{2}$ The communal dimension of this conflict has also been discussed, namely whether there is a collective right to return and reunite the fragments of a dispossessed community in the homeland from which it was uprooted. ${ }^{3}$

In this Article we do not wish to revisit the substantive question of whose right trumps. Instead, we wish to highlight a preliminary matter: who has the authority to resolve these conflicts? Who has the authority to engage in the resolution of such individual and collective conflicts, vindicating either the

1 See, e.g., this journal's volume on 'The Palestinian Refugees and the Right of Return: Theoretical Perspectives', 5 Theoretical InQ. L. (2004); YAel Ronen, Transition From Illegal Regimes Under International LaW (2011); Israel AND the Palestinian Refugees (Eyal Benvenisti, Chaim Gans \& Sari Hanafi eds., 2007).

2 We, too, will focus on the rights of such private owners or residents, bracketing for the sake of discussion the case of other types of third parties such as foreign investors.

3 See, e.g., Gans's discussion of the foundations for national groups' demands to return to their historic homeland, whether based on their first occupancy of it, or based on its formative role in their national identity, Chaim Gans, Historical Rights: The Evaluation of Nationalist Claims to Soveriegnty, 26 PoL. THeory 58 (2001). 
original owners' title or the succeeding resident's expectations? And what justifications underlie this authority and guide its execution?

Our inquiry about authority and process is informed by the fact that it is broadly recognized in both domestic legal systems and international law instruments that the individual right to property is not unlimited. Rather, governments may legitimately take private property or place restrictions on its use for the public good. ${ }^{4}$ This implies that the conflict between the original owners and the more recent residents does not necessarily call for Solomonic justice; rather, public interests may be at play in resolving such disputes, informed by the need, indeed the duty, to promote the public good. A question remains, however, as to how to identify the relevant public whose good informs the resolution of conflicting property claims. Moreover, the question regarding who has the authority to determine what the public good requires and consequently to resolve such conflicts, is key. This is the aim of our Article.

Generally speaking, both domestic and international human rights law grant governments wide discretion when determining which public interests justify deprivation of private property and in balancing the interests of individuals against those of other individuals or the community as a whole. ${ }^{5}$ As we argue in this Article, such discretion is subject to the requirement that any limitation on the right to property rests procedurally on two separate preliminary, necessary (but not sufficient) conditions: inclusion and representation. By inclusion we mean that the entity that interferes with property rights for the public good is capable of internalizing the welfare of the relevant political community as a whole, including the welfare of the individual owner whose property is taken. Despite the harm to her individual property, an owner who is included in the political community is nevertheless thought to benefit from the public good that arises from public takings: if not from the particular taking of her own property, then from other takings in the past, present or future. By representation we allude to the tools necessary to ensure inclusion, so that the authority that decides on limiting property is sufficiently well-informed by, and accountable to, those affected by its decision. A person who is represented by the deciding authority is one to whom the authority is accountable so that the person is

4 See infra Part I.A.. For a general overview of the right to property, see Ursula Kriebaum \& August Reinisch, Property, Right to, International Protection, MAX Planck Encyclopedia of International Law (2019), https://opil.ouplaw.com/ view/10.1093/law:epil/9780199231690/law-9780199231690-e864?print=pdf.

5 Clare Ovey \& Robin C.A. White, Jacobs \& White The European Convention on Human Rights 362-63 (4th ed. 2006) (discussing the European Court of Human Rights jurisprudence in James v. United Kingdom, App. No. 8793/79 Eur. Ct. H.R. (1986) and Pine Valley Developments v. Ireland, App. No. 12742/87 Eur. Ct. H.R. (1991)). 
able to inform decision-making with respect to the taking of property. Such "authority" does not exclusively refer to a political body or a state's executive, but might also refer to an independent and impartial court which is accountable to (or speaks "in the name of") the dispossessed owners and allows them to challenge the taking of their property and in that way inform decision-making.

But which is the relevant political community, and how can inclusion and representation be secured in the context of an inter-state or inter-communal conflict involving refugees wishing to return to their homes? The intuition that motivates this Article is that the demands for inclusion and representation require that the authority that determines property takings ought to have substantial links with those whose property is at stake, as well as with the public whose good is promoted by taking (or otherwise limiting) property rights. When two or more political communities seek to resolve conflicting claims to property rights as part of a post-conflict political settlement, the public interest must include at least these communities, taking into account their respective public goods and seeking to balance them.

In typical attempts to resolve inter-state conflicts, concerns arise with respect to individual property owners who are not part of the political community of any of the negotiating parties and are therefore neither included in the public good nor represented by either negotiating party. A similar concern arises when one party to a conflict moves to unilaterally redistribute property rights in a manner impacting individuals who are not part of its political community and have no impact on the decision-making process. ${ }^{7}$ In this Article we therefore underscore inclusion and representation as preconditions for legitimately settling private property claims in post-conflict negotiations.

It is important to note that the public good in a context of post-conflict negotiations may indeed include the establishment of lasting peace and security. Viable peace may be supported by the resolution of outstanding property claims which may otherwise prolong friction. Inclusion in this context therefore requires that the person whose property is taken be thought to benefit at least from the public good of such peace and security, and from access to whatever compensation scheme is reached in negotiations. Furthermore, persons affected by the international settlement negotiated must be adequately represented by one of the negotiating parties. ${ }^{8}$

6 Armin von Bogdandy \& Ingo Venzke, In Whose Name? An Investigation of International Courts' Public Authority and its Democratic Justification, 23 EuR. J. INT'L L. 7 (2012).

7 Michal Saliternik, Perpetuating Democratic Peace: Procedural Justice in Peace Negotiations, 27 Eur. J. InT'L L. 617 (2016).

8 Although governments often do not represent some of their populations optimally 
The Article proceeds as follows: Part I discusses the right to property under international law, its justifications and constraints, and the conditions required for its limitation or taking. It addresses the issue of rights' conflicts and the instances where a succeeding resident's right to property may be preferred over that of the original owner. It argues that the authority to decide such conflicts, including in the context of post-conflict settlements, is vested with the state in whose community the individual property owner is included and whom it represents. Parts II and III investigate the two requirements of inclusion and representation in the context of the Cyprus conflict and the Israeli-Palestinian conflict, two conflicts that have generated innumerable individual, as well as communal, conflicting claims for property. ${ }^{9}$ While collective efforts to resolve these conflicts await agreement, ${ }^{10}$ the Turkish Republic of Northern Cyprus (TRNC) has established a unilateral mechanism to hear and resolve property claims by Greek-Cypriots for properties located in the territory under its control. We analyze, first, the TRNC's mechanism according to the two conditions - and highlight its flaws with respect to both. However, we consider, further, what we view as attenuating circumstances. Next, we turn to the Israeli-Palestinian context. Israel has sought since 1948 to unilaterally regulate conflicting claims to property. First, within its 1948 borders, and, after 1967, also in East Jerusalem, the West Bank and Gaza. We examine particularly its latest regulatory effort, the recent Regularization Law, ${ }^{11}$ and find it wanting in respect to both requirements. To wit: Palestinians in the West Bank are not included in the public who stands to benefit from the taking

due to various ideological or strategic reasons, we assume that groups have at least some ways to attempt to influence decision-making in this context, whether through various forms of political participation or protest or through the legal system; whether ex ante or in retrospect. See, however, Itamar Mann's contribution to this volume as an important qualifier to this assumption, Itamar Mann, Disentangling Displacements: Historical Justice for Mizrahim and Palestinians in Israel, 21 TheORETICAL INQUIRIEs L. 427 (2020).

9 For a an overview of the Israeli-Palestinian private property claims situation, see Eyal Benvenisti \& Eyal Zamir, Private Claims to Property Rights in the Future Israeli-Palestinian Settlement, 89 Am. J. INT'L L. 295 (1995). For a discussion of private property claims in the context of the Cyprus conflict, see RONEN, supra note 1, at 294-307.

10 Annex on Refugees, The Geneva Accord: A Model Israeli-Palestinian Peace Agreement, 236-38 (2009), http://www.geneva-accord.org/images/PDF/refugees new.pdf; Report of the Secretary-General on his Mission of Good Offices in Cyprus, U.N. Doc.S/2003/398 (Apr. 1, 2003) [hereinafter: The Annan Plan].

11 Law for the Regularization of Settlement in Judea and Samaria, 5777-2017, 2604 SH 410 (Isr.). 
of their property, and were not represented in this unilateral process. Indeed, this law has recently been struck down by the Israeli Supreme Court, based in large part on its failure to meet the criterion of inclusion. ${ }^{12}$ Not only are the circumstances that seem to somewhat atone for the TRNC's flawed meeting of the conditions unmatched in the Israeli case, but the ongoing nature of the Israeli-Palestinian conflict actually seems to aggravate the situation.

\section{The Right to Property and the Authority to Settle Conflicting Property Claims}

\section{A. The Right to Property Under International Law}

The human right to property was recognized by the 1948 Universal Declaration on Human Rights, ${ }^{13}$ but did not find its way into the main international human rights conventions. ${ }^{14}$ Nor was the issue of refugee return to property or their reparation for it addressed by the 1951 Convention relating to the Status of Refugees and its 1967 Protocol. ${ }^{15}$ However, the right to property was recognized by regional human rights conventions, including the European Convention on Human Rights (ECHR) in its Protocol I (as the right to possession), ${ }^{16}$ the American Convention on Human Rights, ${ }^{17}$ and the African Charter on Human

12 HCJ 1308/17 Silwad v. Knesset (June 6, 2020), Nevo Legal Database (by subscription, in Hebrew) (Isr.)

13 G.A. Res. 217 (III) A, Universal Declaration of Human Rights (Dec. 10, 1948), Art. 17 (")(1) Everyone has the right to own property alone as well as in association with others. (2) No one shall be arbitrarily deprived of his property.").

14 Namely, chiefly, the International Covenant on Civil and Political Rights, Dec. 16, 1966, 999 U.N.T.S. 171; International Covenant on Economic, Social and Cultural Rights, Dec. 16, 1966, 993 U.N.T.S. 3.

15 Convention Relating to the Status of Refugees, July 29, 1951, 189 U.N.T.S. 137; Protocol Relating to the Status of Refugees, Jan. 13, 1967, 606 U.N.T.S. 267.

16 Convention for the Protection of Human Rights and Fundamental Freedoms, art. 1 of Protocol no. 1, Nov. 4, 1950, 213 U.N.T.S. 221, entered into force Sept. 3, 1953 [hereinafter: ECHR]:

(1) Every natural or legal person is entitled to the peaceful enjoyment of his possessions. No one shall be deprived of his possessions except in the public interest and subject to the conditions provided for by law and by the general principles of international law. (2) The preceding provisions shall not, however, in any way impair the right of a state to enforce such laws as it deems necessary to control the use of property in accordance with the general interest or to secure the payment of taxes or other contributions or penalties.

17 American Convention on Human Rights art. 21, Nov. 22, 1969, O.A.S.T.S. No. 36, 1144 U.N.T.S. 123, entered into force July 18, 1978 [hereinafter: American 
and Peoples' Rights. ${ }^{18}$ Article 8 of the ECHR also recognizes the right to one's "private and family life, [and to] his home." 19 Rather than provide a comprehensive doctrinal analysis, the following discussion highlights certain aspects of the right to property in international human rights law which are pertinent to the present discussion.

The regional human rights conventions that recognize the right to property further recognize the authority to limit it. However, they subject the exercise of such authority to two conditions. First, the deprivation must be in the interest of the public, the society or the community. ${ }^{20}$ In other words, a person's right to property may be restricted (even taken) due to considerations of the public good. Second, the deprivation must occur under the conditions and in accordance with procedures established by law. ${ }^{21}$ The ECHR also includes

Convention]:

(1) Everyone has the right to the use and enjoyment of his property. The law may subordinate such use and enjoyment to the interest of society. (2) No one shall be deprived of his property except upon payment of just compensation, for reasons of public utility or social interest, and in the cases and according to the forms established by law. (3) Usury and any other form of exploitation of man by man shall be prohibited by law.

18 African Charter on Human and Peoples' Rights art. 14, 1520 U.N.T.S. 217, entered into force Oct. 21, 1986 [hereinafter: African Charter]: "The right to property shall be guaranteed. It may only be encroached upon in the interest of public need or in the general interest of the community and in accordance with the provisions of appropriate laws."

19 ECHR, supra note 16, at art. 8:

(1) Everyone has the right to respect for his private and family life, his home and his correspondence. (2) There shall be no interference by a public authority with the exercise of this right except such as is in accordance with the law and is necessary in a democratic society in the interests of national security, public safety or the economic well-being of the country, for the prevention of disorder or crime, for the protection of health or morals, or for the protection of the rights and freedoms of others.

20 ECHR, supra note 16, at art. 1(1) of Protocol no. 1, which allows for limitation of one's right to possession based on "public interest"; American Convention, supra note 17, at art. 21(1) which determines that "The law may subordinate such use and enjoyment [of the right] to the interest of society", and art. 21(2) which allows for deprivation of private property "for reasons of public utility or social interest"; African Charter, supra note 18, at art. 14 which recognizes encroachment of the right to property "in the interest of public need or in the general interest of the community".

21 ECHR, supra note 16, at art. 1(1) of Protocol no. 1 (subjects limitation of the right to "to the conditions provided for by law"); American Convention, supra note 17 , at art. 21 which determines that limitation will be done "in the cases 
a condition that deprivation shall be in accordance with general principles of international law. ${ }^{22}$ The American Convention adds the condition of just compensation in cases of deprivation. ${ }^{23}$

The protection of the right to possession enumerated in Protocol I to the ECHR has been interpreted by the European Court of Human Rights (ECtHR) to extend not only to legally owned property, but also to de facto possession of property, even if illegally obtained. ${ }^{24}$ Emphasis is placed on the expectations created in fact in the mind of the individual who claims the right. ${ }^{25}$ This concern for acquired expectations is reflected in the jurisprudence of the ECtHR with respect to home expropriations by Communist regimes where residency rights had been transferred to third parties. ${ }^{26} \mathrm{As}$ this jurisprudence indicates, property rights may be invoked not only by original owners deprived of their property, but also, in certain circumstances, by succeeding residents..$^{27}$ The new regimes in many formerly Communist countries annulled the expropriations done by their predecessors, but refrained from evicting third-party individuals or their descendants from the premises. The court recognized this practice and underscored the discretion of state parties in choosing how to remedy the

and according to the forms established by law"; African Charter, supra note 18 , at art. 14 which conditions encroachment of the right to its execution "in accordance with the provisions of appropriate laws."

22 ECHR, supra note 16, at art. 1(1) of Protocol no. 1.

23 American Convention, supra note 17, at art. 21(2).

24 Öneryildiz v. Turkey, 657 Eur. Ct. H.R., ๆ 124 (2004):

The Court reiterates that the concept of 'possessions' in the first part of Article 1 of Protocol No. 1 has an autonomous meaning which is not limited to ownership of physical goods [...] The concept of 'possessions' is not limited to 'existing possessions' but may also cover assets, including claims, in respect of which the applicant can argue that he has at least a reasonable and 'legitimate expectation' of obtaining effective enjoyment of a property right.

$25 I d$. at 9 甲ा 124, 126-29.

26 Brumărescu v. Romania, 105 Eur. Ct. H.R. (art. 41, Just Satisfaction, 2001).

27 The rights of original owners as well as those of succeeding residents may be further protected by the human rights to enjoy and practice culture, religion or language in community with other members of one's group, under the International Covenant on Civil and Political Rights, supra note 14, at art. 27. A similar interest seems to be protected by peoples' right to self-determination when exercised within the bounds of a state, International Covenant on Civil and Political Rights, supra note 14, at art. 1; International Covenant on Economic, Social and Cultural Rights, supra note 14, at art. 1; Re Secession of Quebec, [1998] 2 S.C.R. 217 (Can.). 
injury they caused to their own citizens who were the original owners. ${ }^{28}$ The Inter-American Court of Human Rights has moreover recognized states' exclusive competence to decide conflicting property claims of indigenous communities to their ancestral lands, on the one hand, and current residents or owners, on the other hand..$^{29}$

These cases expose the tensions between individual right and public good, and the delicate balancing exercise that a public authority must perform in determining the taking of property. In property conflicts that occur within the bounds of a state, regional courts have deferred to governments to care for the good of the public as a whole, including both original owners and succeeding residents, and particularly with respect to "economic and social issues on which opinions within a democratic society may reasonably differ widely." ${ }^{30}$ They have recognized the legitimacy of states' preference for stability and safeguarding a peaceful status quo, especially where the harm to original owners is set off by compensation schemes.

However, international human rights law limits states' discretion in circumstances in which they are inclined to discriminately prefer the interest

28 Brumărescu v. Romania, supra note 26, at 920.

29 The Sawhoyamaxa Indigenous Community v. Paraguay, Merit, Reparations and Costs, Judgment, Inter-Am. Ct. H.R. (ser. C) No. 146, \136 (March 29, 2006):

[...] [T] he Court can not to decide that Sawhoyamaxa Community's property rights to traditional lands prevail over the right to property of private owners or vice versa, since the Court is not a domestic judicial authority with jurisdiction to decide disputes among private parties. This power is vested exclusively in the Paraguayan State. Nevertheless, the Court has competence to analyze whether the State ensured the human rights of the members of the Sawhoyamaxa Community.

30 James v. United Kingdom, 2 Eur. Ct. H.R. ๆ 46 (1986):

[T] he notion of 'public interest' is necessarily extensive. In particular, as the Commission noted, the decision to enact laws expropriating property will commonly involve consideration of political, economic and social issues on which opinions within a democratic society may reasonably differ widely. The Court, finding it natural that the margin of appreciation available to the legislature in implementing social and economic policies should be a wide one, will respect the legislature's judgment as to what is 'in the public interest' unless that judgment be manifestly without reasonable foundation.

See also Stec v. United Kingdom, 393 Eur. Ct. H.R. ๆ 52 (2006):

[A] wide margin is usually allowed to the State under the Convention when it comes to general measures of economic or social strategy [...]. Because of their direct knowledge of their society and its needs, the national authorities are in principle better placed than the international judge to appreciate what is in the public interest on social or economic grounds, and the Court will generally respect the legislature's policy choice unless it is 'manifestly without reasonable foundation'. 
of one group over another. The International Convention on the Elimination of All Forms of Racial Discrimination (CERD) prohibits discrimination on the basis of race, colour, or national or ethnic origin with respect to the enjoyment of the right to own property. ${ }^{31}$ This nondiscrimination rule has also been found to have support in other conventions' prohibition on discrimination, such as Article 26 of the International Covenant on Civil and Political Rights. As the Human Rights Committee explained,

$[\mathrm{t}]$ he right to property as such is not protected under the Covenant. However, confiscation of private property or failure by a State party to pay compensation for such confiscation could still entail a breach of the Covenant if the relevant act or omission was based on discriminatory grounds, in violation of article 26 of the Covenant. ${ }^{32}$

That said, the ECtHR has recognized a legitimate distinction that may be made between nationals and non-nationals with respect to compensation for expropriation. This distinction rests on two grounds: first, non-nationals are not represented in the government or in national lawmaking informing the taking of property and are therefore more vulnerable to it than nationals. ${ }^{33}$ Second, the court stated that "although a taking of property must always be effected in the public interest, different considerations may apply to nationals and non-nationals and there may well be legitimate reasons for requiring nationals to bear a greater burden in the public interest than non-nationals." ${ }^{34}$ We understand this second point as resting on the assumption that nonnationals cannot be presumed to benefit (or to benefit to the same extent) from the increase to the public interest that arises from the taking, since it is not clear that they are equally part of the public. For this reason, nationals may be required to bear a greater burden in the name of the public interest.

31 International Convention on the Elimination of All Forms of Racial Discrimination, art. 5(d)(v), Dec. 21, 1965660 U.N.T.S. 195, adopted and opened for signature and ratification by General Assembly in G.A. Res. 2106 (XX) (Dec. 21, 1965).

32 Somers v. Hungary, Judgment, U.N. Doc. CCPR/C/53/D/566/1993 (23 July 1996), at ๆๆ 9.2-9.4, 9.6, 9.8, 10. Similarly, see Adam v. Czech Republic, Merits, U.N. Doc. CCPR/C/57/D/586/1994 (23 July 1996), at ๆ甲 2.1, 12.2, 12.4-12.7, 13.1 \& Individual Opinion by Nisuke Ando (concurring), at 173. See also Convention on the Elimination of All Forms of Discrimination Against Women, Dec. 18, 1979, 1249 U.N.T.S. 13, art. 16.1(h).

33 James v. United Kingdom, supra note 30, at 63.

34 Id. 
The margin of appreciation ${ }^{35}$ granted to governments in taking property or determining conflicting property claims can therefore plausibly be interpreted as including the two criteria we outlined in the introduction: inclusion and representation. Even though their own property was taken, or even though a succeeding resident is recognized as the rightful possessor, original owners may be held to benefit from the public utility gained by the taking of their property, or from other takings in the past, present or future, and they are viewed as represented by the government making the determination. Put differently, the discretion afforded to governments rests on a perception which views property owners as embedded in the political community they govern.

\section{B. Ex Injuria Ius non Oritur and Waldron's Supersession Thesis}

Both courts and scholars have addressed the question regarding the conditions under which succeeding residents qualify for protection despite the legitimate claim of the property's original owner. An overview would be helpful to set the scene for a discussion of what is at stake when parties attempt to resolve such disputes. The maxim ex injuria ius non oritur (wrongdoing cannot create law) is a general principle of law, also at work at international law. ${ }^{36}$ Generally, it requires that individuals - or states - who are responsible for a wrongful act shall not benefit from that act. Therefore, an intuitive objection may arise with respect to recognition of the property rights of succeeding residents in properties originally owned by refugees or internally displaced persons.

Nevertheless, considering instances of historic injustice, including one's illegitimate possession of another's rightful property, Jeremy Waldron has argued that "a change in circumstances can affect whether a particular continuation of adverse possession remains an injustice or not." ${ }^{\prime 7}$ According to Walrdon's "supersession thesis," this is because the primary focus of justice is on the present, and present-day considerations may render the adverse possession

35 On considerations of representation and political voice in general in the use of the "margin of appreciation" doctrine, see Eyal Benvenisti, The Margin of Appreciation, Subsidiarity, and Global Challenges to Contemporary Democracies, 9 J. Int'L Dispute Settlement 240 (2018); Eyal Benvenisti, Margin of Appreciation, Consensus and Universal Standards, 31 N.Y.U. J. InT'L L. \& PoL. 843 (1999).

36 For elaboration on the status of the maxim as a general principle of law and its place in international law, see Christopher R. Rossi, Ex Injuria Jus Non Oritur, Ex Factis Jus Oritur, and the Elusive Search for Equilibrium After Ukraine, 24 Tulane J. Int. Comp. Law 143 (2015).

37 Jeremy Waldron, Settlement, Return, and the Supersession Thesis, 5 TheORETICAL INQUiRIES L. 237, 242 (2004). 
presently just despite its unjust heritage. ${ }^{38}$ It may even be the case, he stresses, that the change which has led to supersession is "the immediate causal product of the very injustice originally complained of." 39 Among other situations, when current occupants are reliant on the existing situation whereas the dispossessed owners have in the meantime managed to find alternative means of accommodation and subsistence, ${ }^{40}$ restitution would not be required by considerations of justice.

As exemplified by the jurisprudence discussed above, considerations similar to the supersession thesis seem to underlie decisions to limit the rights of original owners for the benefit of succeeding residents. ${ }^{41}$ Such decisions may further be justified by public good considerations of social, economic or political stability.

\section{Separating Harm from Remedy: The Pragmatic Approach}

Therefore, a key question is how to determine whether circumstances have indeed changed so that present-day considerations of justice would determine that restitution of private property is no longer just, due to the legitimate expectations of succeeding residents. ${ }^{42}$ Waldron's suggestion makes a distinction between primary and secondary rights; it separates the question of the breach of the right from the question of remedying the harm caused.

There may be several moral and policy reasons to distinguish between primary norms, which define rights and obligations, from secondary norms,

\section{Id. at 246.}

39 Id. at 243.

40 Yaël Ronen, The Dispossessed and the Distressed: Conflicts in Land-Related Rights in Transitions from Unlawful Territorial Regimes, in CONFLict BeTweEN Fundamental Rights 521, 545 (Eva Brems ed., 2008).

41 Somers v. Hungary (566/1993), ICCPR, A/51/40 vol. II (23 July 1996) 144 (CCPR/C/57/D/566/1993), at ๆ 9.2-9.4, 9.6, 9.8 \& 10:

The Committee does not consider that the fact of giving the current tenants of former State-owned property priority in the privatization sale of such property is in itself unreasonable; the interests of the 'current tenants', who may have been occupying the property for years, are deserving of protection. If the former owners are, moreover, compensated on equal and non-discriminatory terms [paragraph 9.6], the interplay between Act XXV of 1991 and of Act LXVIII of 1993 can be deemed compatible with article 26 of the Covenant.

See, similarly, Adam v. Czech Republic (586/1994), ICCPR, A/51/40 vol. II (23 July 1996) 165 , ๆ $2.1,12.2,12.4-12.7,13.1$ \& Opinion by Nisuke Ando (concurring), 173.

42 Waldron, supra note 37, at 249. 
which define the consequences of breach. One particularly relevant reason is that a breach of a primary norm may have irrevocably changed the circumstances or otherwise rendered a reversion to the previous state of affairs impossible, unjust or undesirable. That would have direct implications for the application of the secondary norm, for instance regarding a choice between restitution or monetary compensation.

The need to separate primary from secondary rights is also recognized in international law. ${ }^{43}$ Post-conflict settlements of private property rights between states often separate the question of the potential wrongfulness of acts leading to displacement from the determination of its consequences. As already suggested, such a move is legitimated by the added value of bringing an end to the conflict, securing peaceful relations and ensuring some form of reparations for displaced persons, which contributes to the public good of both communities.

The International Court of Justice (ICJ) likewise separated the international wrongfulness of an act from the determination of (at least some of) its consequences in its 1971 advisory opinion on the South African presence in Namibia. ${ }^{44}$ In this opinion, the ICJ asserted that the South African control over Namibia is prohibited under international law and that its illegality warrants that states not recognize such control or its consequences. States should therefore refrain from entering into or upholding any legal, diplomatic or economic ties with South Africa in respect of Namibia or Namibia's territory. Nevertheless, the Court stressed that such legal nullity should not also cover international rights and advantages guaranteed to Namibian citizens through South Africa's international obligation to provide or protect these rights. Similarly, official acts performed by South Africa in Namibia, such as the registration of births, deaths, marriages and so on, would continue to be recognized due to their profound importance for the inhabitants of the territory. In the words of the Court:

In general, the non-recognition of South Africa's administration of the Territory should not result in depriving the people of Namibia of any advantages derived from international co-operation. In particular, while official acts performed by the Government of South Africa on behalf of or concerning Namibia after the termination of the Mandate are illegal and invalid, this invalidity cannot be extended to those acts, such as, for instance, the registration of births, deaths and marriages, the

43 Ronen, supra note 40, at 545.

44 Advisory Opinion on Legal Consequences for States of the Continued Presence of South Africa in Namibia (South West Africa) Notwithstanding Security Council Resolution 276 (1970) [1971] I.C.J. Rep. 16. 
effects of which can be ignored only to the detriment of the inhabitants of the Territory. ${ }^{45}$

So, the Namibia opinion adopts a general principle of non-recognition of the consequences of internationally wrongful acts, but recognizes a carve-out for a particular subset of those consequences: those whose preservation is actually beneficial to the population that was already harmed by the original wrongful act. In other words, the court's guiding principle is to safeguard the public good of the already-deprived population. In the context of South African control in Namibia, this good seemed to include, at a minimum, the ability to live under some system of law and have a minimal sense of order and stability, even at the cost of recognizing certain acts of an illegal regime. As the court itself emphasizes, "As to the general consequences resulting from the illegal presence of South Africa in Namibia, all States should bear in mind that the injured entity is a people which must look to the international community for assistance..." ${ }^{46}$ In other words, the guiding principle in determining how to regard the acts of the illegal regime should be safeguarding the interests of the injured people under its control.

The ICJ's separation of harm from remedy was geared to protect the subjects of an illegal regime. In a case relating to the practice of the Turkish-Cypriot administration, the ECtHR adopted a similar approach in order to resolve the conflicting rights of two communities-Greek Cypriots and Turkish Cypriots - that have both been impacted by illegal measures. ${ }^{47}$ The court stressed that "the key consideration is to avoid a vacuum which operates to the detriment of those who live under the occupation, or those who, living outside, may claim to have been victims of infringements of their rights." ${ }^{48}$ In other words, both the ICJ and the ECtHR held that disregarding the illegality of a regime and recognizing its effects are generally the proper course of action, but only when doing so would be in the interest of the populations already harmed by that regime.

Thus, the holdings of both courts reflect a pragmatic approach that aims to address the everyday concerns of distressed communities without allowing norms of international law that pertain to inter-state relations to get in the way. The principle driving this approach champions the good of the community or

45 Id. at 125.

46 Id. at 9127.

47 Demopoulos v. Turkey, Admissibility, App. No. 46113/99, Eur. Ct. H.R. (Mar. 1, 2010), at 94 ("the mere fact that there is an illegal occupation does not deprive all administrative or putative legal or judicial acts therein of any relevance under the Convention"). 
communities already adversely affected by an illegal situation. This pragmatic approach necessarily carries long-term effects also beyond the period of occupation, as in the case of the registration of marriages. This has effects also in the context of registration of property transactions that shape the expectations of third parties. The same approach could also legitimize settling conflicting property claims in the aftermath of international conflict, even if such resolution entails that some individual owners' rights be sacrificed for the benefit of their community. It would therefore justify obtaining restitution where feasible, but settling on compensation in other cases, all in order to allow individuals and communities to rebuild their lives and establish long-lasting peace. Importantly, however, the pragmatic approach does not provide ex ante approval for policies or practices otherwise prohibited by international law by promising in advance to separate their illegality from its consequences.

\section{Deprivation of Private Property: Identifying the "Public" and the "Authority"}

Governments have wide discretion in identifying the public interest and determining what public interests justify deprivation of private property. Moreover, they have discretion in balancing the interest of individuals against one another, or against the community as a whole. ${ }^{49}$ This discretion is grounded in the presumption that the authority making such determination - in domestic property conflicts, the government - is operating in accordance with law and for the benefit of the community at large. Property owners whose rights have been limited, or whose property has been taken for public use or benefit, are therefore assumed to enjoy at least some dividend of the public good derived from the particular taking or from other takings in the past, present or future. ${ }^{50}$ In addition, the requirement that taking is done in accordance with legal procedure is grounded in the individual owner's franchise and opportunity to influence decision-making in her state. ${ }^{51}$

49 Over \& White, supra note 5, at 362-63.

50 Hanoch Dagan, Takings and Distributive Justice, 85 VA. L. REv. 741, 769-70 (1999).

51 For a similar argument about the normative limitations on private property, see Hanoch Dagan \& Michael Heller, Chapter 8: Property in Transitions, in $\mathrm{HANOCH}$ Dagan, A Liberal Theory of Property 291 (forthcoming 2020) (arguing that a "liberal property pact" which undergirds a property regime "presupposes that the owner is part of the benefitted community - a co-citizen of the pertinent state or member of the relevant locality" and that "the power of a polity detrimentally to affect property rights must be delimited to the rights of its own members"). 
Things get murkier, however, when the person deprived of property is not part of the community whose public good is augmented by the taking (for instance, because she is not a citizen or a resident of that country), and consequently cannot be deemed to either enjoy a share of the public utility, nor to have her interest represented by those making the decision. The justification to limit or extinguish property rights of such a person seems to be weaker.

Broad discretion is also justified when states establish international arrangements that settle private property rights' claims in post-conflict situations. When negotiating peace settlements in the aftermath of conflict, states may take into account considerations of public interest or public good, and ascribe weight to the public good of ending violent conflict and establishing peace and security. The prospects of such peace could be undermined by outstanding claims which would serve as "sources of friction" between the two sovereigns. ${ }^{52}$ Against these considerations, states may choose to forfeit in whole or in part property claims of individuals belonging to their community which are located in the territory of the other state. In doing so, the negotiating governments may be deemed to redistribute both private property rights and public good across their communities, in the name of peace and security.

However, concerns arise when states opt for unilateral settlement of property disputes in the context of international conflict. This could be the case, for instance, when one side to a conflict seeks to extinguish the property rights of owners who are not part of its political community and therefore are neither included in the public whose good is augmented nor represented by the deciding authority. Another point of concern is when the interests of property owners are not represented by any of the negotiating authorities, for instance because they are nationals of a third state or are stateless. In addition, the justifications for post-conflict settlement of private property claims are weaker when the public good of peace and security is not expected to be a dividend from which the dispossessed owner can hope to benefit.

Finally, post-conflict settlement of private property is justified in the circumstances outlined above very much due to the fact that it is embarked on from an ex post perspective. The goal is to turn the page on a painful history and enable a new, clean slate. To this end, post-conflict arrangements may regularize and consequently also legitimize instances of adverse possession which originally may have been obtained unjustly or illegally. They do so with a view to considerations of justice in the present, rather than in order to cement past injustices. What they do not do, however, is set out rules for the future regulation of property rights. In other words, they do not legitimize

52 Dames \& Moore v. Reagan, 453 U.S. 654, 679-80 (1981) (quoting Louis HenKin, Foreign AfFairs And the Constitution 262 (1972)). 
additional, future takings or future limitation of property rights through similar adverse possessions. Conversely, setting ex ante guidelines which legitimate future unjust or illegal possession of property is tantamount to incentivizing a breach of property rights, and is clearly not justified.

$* * *$

From the above we can conclude that the right to property under international human rights law is a limited right, as governments enjoy discretion in limiting property rights. However, this discretion rests on the presumption that the property owner is part of the political community to which the government is accountable. Owners should be included in the public whose good is served by the taking of property, and they should be adequately represented by the government so as to have a voice in the process of decision-making. The discretion to take private property is therefore also limited, and requires that the conditions of inclusion and representation are met in order to ensure that all members of the community enjoy a share of the augmented public good. A unilateral attempt by a government to regulate post-conflict property rights is therefore suspect when the owners are individuals who are not part of the relevant community, and who are not represented by the said government. When two governments negotiate towards post-conflict arrangements, we suggest that they may legitimately settle private property claims of owners who are part of their communities with the aim of upholding the public good of all involved by advancing peace and security. These justifications, however, do not easily extend to owners who are not part of the political community of either state, or who cannot be deemed to benefit from the peace and security advanced. In the following two Parts, we discuss two instances of unilateral attempts to regulate post-conflict property rights - the claims commission established in Turkish Cyprus, and the Regularization Law enacted by Israeland consider whether they are justified in light of the preceding discussion.

\section{Conflicting Property Rights Claims in NORTHERN CYPRUS}

The contemporary paradigmatic case of a unilateral move to settle property claims in the aftermath of conflict is that of the claims commission established by the Turkish Republic of Northern Cyprus (TRNC) in order to adjudicate and compensate for the loss of private property located in the north of the island and owned by Greek-Cypriots.

Cyprus was established as an independent state in 1960, following British colonial rule. However, the Greek-Cypriot majority and the Turkish-Cypriot 
minority have struggled to share power under a unitary system of government. After years of civil strife, in 1974 Turkey invaded the island and installed de facto territorial separation of the two communities that effectively ended intercommunal hostilities. ${ }^{53}$ In the early years following the Turkish invasion, UN General Assembly resolutions called for respecting the rights of the refugees to return and to regain control over their property. However, subsequent efforts to resolve the conflict by successive Secretaries-General strove to strike a balance between the interests of the displaced persons and the goal of creating homogeneous communities with a view to avoiding interethnic tensions. Such proposals endorsed a territorial separation between the communities along ethnic lines with only a limited and gradual return of refugees. ${ }^{54}$ In 1992 , Secretary-General Boutros Ghali's "Set of Ideas on an Overall Framework Agreement on Cyprus" 55 called for such an arrangement, and was subsequently endorsed by the Security Council. ${ }^{56}$ Secretary-General Kofi Annan's 2003 plan acknowledged the "legitimate claims" of both the refugees and those who currently reside in their property, and attempted to strike a compromise between the two warring communities that would allow for a limited and gradual return of only some of the refugees. ${ }^{57}$ Annan's plan was also endorsed by the UN Security Council. ${ }^{58}$

The Annan Plan proposed a complex treatment of property claims. In areas subject to territorial adjustments, properties would be restored to their former owners. However, in other areas, dispossessed owners could choose between a combination of restitution and compensation options. ${ }^{59}$ The plan recognized exceptions which protected the rights of current users and allowed them to

53 Robert McDonald, The Problem of Cyprus, 29 (234) Adelphi PAPers 1, 49-50 (1989).

54 U.N. Secretary-General Mr. Perez de Cuellar's opening statement of June 29, 1989, reproduced in Zaim M. Necatigil, The Cyprus Question and the Turkish Position in International Law 433 (2nd ed. 1993) (Appendix 10).

55 U.N. Secretary-General, Report of the Secretary-General on his Mission of Good Offices in Cyprus, 9-25, U.N. Doc. S/24472, annex (Aug. 21, 1992) [hereinafter: The Boutros Ghali Plan].

56 S.C. Res. 774 (Aug. 25, 1992).

57 The Annan Plan, supra note 10.

58 S.C. Res. 1475, § 4 (Apr. 14, 2003) (giving full support to the Secretary-General's carefully balanced plan of 26 February 2003 as a unique basis for further negotiations, and calling on all concerned to negotiate within the framework of the Secretary-General's good offices, using the plan to reach a comprehensive settlement as set forth in paragraphs 144-151 of the Secretary-General's report).

59 See overview in Demopoulos v. Turkey, App. No. 46113/99, Eur. Ct. H.R. (Mar. $1,2010)$, at $\uparrow \uparrow 10-15$. 
apply in order to receive title of the property they occupied, in exchange for their relinquishment of their rights to property left behind in the south of the island. ${ }^{60}$ The settlement of claims was to be administered by "an independent, impartial Property Board, governed by an equal number of members from each constituent state [Greek Cyprus and Turkish Cyprus], as well as non-Cypriot members" ${ }^{61}$ On 24 April, 2004, the Annan Plan stood for authorization through referenda by both communities but failed to receive the endorsement of the Greek-Cypriots, and therefore never entered into effect. ${ }^{62}$

On 30 June, 2003, the TRNC enacted Law no. 49/2003 on compensation for immovable properties located within the boundaries of the TRNC. Pursuant to this law, it established an "Immovable Property, Determination, Evaluation and Compensation Commission" (IPC) which offered a mechanism for providing compensation to dispossessed Greek-Cypriots for their immovable property left in the northern part of island. ${ }^{63}$ The ECtHR reviewed this law in the case of Xenides-Arestis and ruled that it did not provide an appropriate remedy for several reasons, including that compensation was limited to "pecuniary loss for immovable property, without provision for movable property or non-pecuniary damage"; 64 the law did not provide the option of restitution of property; and "the composition of the compensation commission gave rise to difficulties, the Government not disputing that the majority of IPC members lived in houses owned or built on property of Greek-Cypriots." ${ }^{65}$ The Court commented that "an international composition would enhance the commission's standing and credibility." 66

Following the Court's pronouncements in Xenides-Arestis, the TRNC enacted Law no. 67/2005, setting up a new IPC and implementing the Court's comments. ${ }^{67}$ The new commission consisted of five to seven members, of whom two were foreigners. ${ }^{68}$ Persons who occupy Greek-Cypriot property

60 Demopoulos v. Turkey, App. No. 46113/99, Eur. Ct. H.R. (Mar. 1, 2010), at $\uparrow \uparrow$ $10-15$.

$61 \quad I d$. at 914.

62 Xenides-Arestis v. Turkey, Judgment, App. no. 46347/99, Eur. Ct. H.R. (Mar. $22,2006)$, at 13 .

$63 I d$. at 12.

64 Xenides-Arestis v. Turkey, Admissibility, App. no. 46347/99, Eur. Ct. H.R. (Mar. 14, 2005) as summarized in Demopoulos v. Turkey, supra note 60, at 9 73.

65 Demopoulos v. Turkey supra note 60, at 973.

$66 I d$.

$67 \quad I d$. at 50.

$68 I d$. at 75. 
were expressly prevented from serving on the commission. ${ }^{69}$ The ECtHR gave its stamp of approval to the new mechanism in the case of Demopoulos. ${ }^{70}$

In accordance with the considerations outlined above, the TRNC mechanism is to be faulted for its unilaterality; for presuming to settle rights' claims by individuals who are not part of its political community and who cannot be said to be validly represented by it; and for failing to secure long-term peace or security as a mitigating public good against the taking of private rights.

Nevertheless, as the ECtHR has noted, several aspects of the mechanism attenuate these difficulties. First, although it is not established through an international arrangement as envisaged by the Annan Plan, the body established to hear individuals' claims includes members who are non-TRNC nationals and who "enhance the commission's standing and credibility". ${ }^{71,72}$ Represented by the TRNC, their interests are also governed and protected by the foreign IPC representatives and regional bodies such as the ECtHR, which in a sense serve as their guardians. Importantly, the ECtHR, whose composition is balanced and cannot be regarded as structurally partial to the TRNC, provides the dispossessed owners a venue to express their voice and a way to challenge and hold the IPC to account, and thus participate in shaping the decision-making process. The condition of representation therefore seems to be met to some degree.

However, there are several countervailing concerns. First, such internationalization of the Greek-Cypriots' representation does not fully atone for their inability to influence the process through their representatives as a community. In fact, because not all members of the community can have recourse to this mechanism, this plan divides the community and thereby might undermine its cohesion. Further, individual owners may be driven (rationally) to choose the compensation on offer rather than wait for a comprehensive political settlement that is not currently in sight. The ensuing dynamics of divide and conquer within the community of Greek-Cypriots may undermine their collective bargaining power in negotiating a comprehensive settlement in the future. Moreover, other issues such as symbolic resolution of international grievances cannot be attained through piecemeal individual settlement. The

$69 \quad I d$. at 120.

70 Id. at $9 \uparrow 119-120$.

71 Id. at 973.

72 Further, the commission's rulings are subject not only to appeal before the TRNC High Administrative Court, but also to subsequent supervision by the ECtHR. [FN 72] Greek-Cypriots who were deprived of their property by the TRNC are therefore not ultimately subject to the power of the same state that deprived them of their rights in the first place. And even though they are not part of the political community. 
sum of the parts seems smaller than the whole in this case. The IPC mechanism also does not satisfy the condition of inclusion: Greek-Cypriots do not stand to benefit from the public good augmented by IPC mechanism as they are not members of the relevant public.

Nevertheless, the circumstances of Cyprus are such that hostilities are no longer ongoing. Although various attempts to bring the conflict to a final and formal resolution have failed, the static separation of the northern, Turkishcontrolled part of the island from the southern, Greek-Cypriot part has been a peaceful, longstanding fact. ${ }^{73}$ Therefore, no new breaches of property rights are expected. The IPC mechanism is thus not an ex ante permission for property deprivation, but rather an ex post remedy for past breaches. Assessed in light of the pragmatic approach discussed above, this fact seems to somewhat attenuate its flaws in respect of inclusion and representation.

\section{Conflicting Property Rights Claims in the IsRaeli-Palestinian Conflict}

The Israeli-Palestinian conflict has given rise to several types of dispossession and adverse possession conflicts that fit within the types of property rights conflicts addressed in this Article. Especially pertinent to the present context are cases involving (1) the rights of Palestinians dispossessed during or immediately after the 1948 War, with respect to property located in the post-1948 territory of the State of Israel; (2) the rights of Jews dispossessed before or during the 1948 War of homes in East Jerusalem, the West Bank and Gaza; and (3) the rights of Palestinians on whose properties in East Jerusalem, the West Bank or Gaza Jewish settlements have been established since 1967. ${ }^{74}$ Our focus in this Article is on the last category, and the following overview of the first two is brought in order to provide context.

In the years immediately following the 1948 War and the establishment of the State of Israel, Israel moved to regulate the first type of property claims. It seized the property of mainly Palestinian absentees (but also some Jewish absentees who were at that time in Arab countries) and assigned it

73 Since the August 1974 ceasefire and the subsequent expansion of the operations of the United Nations Peacekeeping Force in Cyprus (UNFICYP) in the buffer zone established along the "green line", Security Council Resolution 361 (30 Aug. 1974)

74 For a detailed overview of the history of the conflict and its impact on private property, see, Benvenisti \& Zamir, supra note 9, at 296-317. 
to the Custodian for Absentees' Property. ${ }^{75}$ The Custodian was entrusted with safeguarding the property, ${ }^{76}$ but an exception allowed for the sale of the property to the Development Authority (a governmental unit which was later established) or to lease it. ${ }^{77}$ In cases when absentee property was sold in this manner, the compensation received for the property was held by the Custodian. ${ }^{78}$ This post-1948 regulation of Palestinian property in Israel seems to at least formally recognize the need to defer the ultimate resolution of property claims to negotiations for peace. ${ }^{79}$

The legal construction of this deferral is somewhat complex. The Supreme Court of Israel has long held that a seizure of property and its assignment to the Custodian extinguishes all property rights of the original owner, and the latter has no say in the administration of property seized.$^{80}$ It has also held that the Custodian's empowerment by law to "release" the property or its monetary equivalent into the hands of the original owner would entail the creation of new property rights, rather than a revival of old rights. ${ }^{81}$ Nevertheless, the court has also recognized that such new rights in the property or in the funds would be "of the same kind and the same scope" of the property rights taken and that no other person but the original owner is eligible to obtain these new rights. ${ }^{82}$ Furthermore, it has explained that the aim of seizing and assigning property to the Custodian includes safeguarding the property "for its owners." 83 Alongside this aim, the assignment to the Custodian is aimed at utilizing the property for the needs of the State of Israel, and to "hold the properties, or their worth, until the conclusion of political arrangements between Israel and its neighbors, in which the fate of the property shall be determined on the basis of reciprocity between the countries." ${ }^{4}$ These arrangements have therefore retained some recognition of the "original owners' expectation to

75 Absentee Property Law, 5710-1950, art. 4, 87 SH 86 (1950) (Isr.) [hereinafter: Absentee Property Law].

76 Id. at art. 7(a).

77 Id. at art. 19(1),(2); Land Requisition (Validation of Acts and Compensation) Law, 5713-1953, art. 2, 3, 122 SH 58 (1953) (Isr.) [hereinafter: Land Requisition Law].

78 Absentee Property Law, art. 28(c).

79 HCJ 3103/06 Valeiro v. Israel (Feb. 6, 2011), Nevo Legal Database (by subscription, in Hebrew), at 29.

80 CA 263/60 Kleiner v. Administrator of Inheritance Tax, 14(3) PD 2521, 2544 (1960).

81 Id. at 2544.

$82 I d$. at 2544.

83 HCJ 4713/93 Golan v. Special Committee, 48(2) PD 638, 644-45 (1994).

84 Id. at $644-45$. 
regain possession of the property in the future, according to decisions made after the war." ${ }^{85}$ In our analysis, this deferral implies recognition of the need to ensure that final determination of property claims is done in a process in which the dispossessed owners are, too, represented by a negotiating government.

Nevertheless, it should be noted that the original owners' right of possession (as opposed to compensation) may be finally extinguished if the Custodian granted rights in the property to third parties. In such a case, the succeeding residents' rights are protected by law. ${ }^{86}$

Following the 1967 Israeli occupation of East Jerusalem, the West Bank, and the Gaza Strip, Israel applied its law, jurisdiction and administration to East Jerusalem. ${ }^{87}$ It later enacted a law which entrusted properties in East Jerusalem that had belonged to Jewish owners prior to the 1948 Jordanian conquest, to the Israeli General Custodian. ${ }^{88}$ The Custodian is instructed by this law to release these properties or their worth back to the original owners or their heirs. ${ }^{89}$ Based on this law, the Israeli Supreme Court has recognized a release of a property in East Jerusalem which was assigned to the Custodian into the hands of its original Jewish owners, paving the way for the evacuation of Palestinians who had lived there for decades..$^{90}$

A different legal regime was applied in the West Bank, administered by the Israeli military under the law of occupation. That regime tasked the IDF Custodian of Governmental Property to administer the pre-1948 property rights of Jewish owners that had been held since 1948 by the Jordanian Custodian of Enemy Property. ${ }^{91}$ The IDF Custodian has consistently denied the requests of Jewish owners to return to that property, and the Israeli courts have endorsed that position. ${ }^{92}$

Israel's repeated attempts to regulate private property claims of Palestinians in both the post-1948 context (under domestic law) and the post-1967 context (under the framework of occupation law) have been made with at least nominal recognition of its uncertain position to do so finitely. The mechanisms of

85 Valeiro, supra note 79 , at $₫ 29$.

86 E.g., Absentee Property Law, art. 17 (Validity of Transactions). See also Absentee Property Law, art. 14 (Cultivator and his Right to the Produce); Land Requisition Law, arts. 2, 3.

87 Law and Administration Order (No. 1), 5727-1967, 2064 KT 2690 (Isr.).

88 Legal and Administration Matters Law [Consolidated Version], 5730-1970, 603 SH 138 (Isr.).

89 Id. at art. 5.

90 See, e.g., HCJ 7446/17 Mahr Sarhan v. General Custodian (Nov. 21, 2018), Nevo Legal Database (by subscription, in Hebrew) (Isr.).

91 Valeiro, supra note 79 , at $\$ 53$.

92 E.g., id. 
seizing property ownership or property use and possession rights, and assigning them to a custodian rather than simply expropriating them, indicate a formal deference of the rights' final resolution to international political settlement. As explained by the Supreme Court in the case of Valeiro, "The assumption is that once property has been assigned to the Custodian of Enemy Property in its various incarnations, its release, or the repayment of its value, awaits a peace settlement." 93

We view this formal position as justified by the normative principles governing states' regulation of property rights following a conflict. Large-scale post-conflict redistribution of property rights and determination of adverse possession situations en masse ought to be guided by considerations of the public good of all affected communities and decided by them. The distinction in policy and practice with respect to Jewish property, in what Israel considers its own territory (including East Jerusalem) and in the West Bank, further indicates that Israel, too, has in the past recognized the limits on its ability to extinguish private property claims in areas not under its sovereignty, and the need to defer such settlement to international political negotiations.

For a brief period in the 1990s, it seemed as if the Israeli-Palestinian conflict was heading towards resolution. As Israeli and Palestinian representatives negotiated towards a solution, one item on the agenda for negotiation was the resolution of private property claims. ${ }^{94}$ Today, however, the resolution of the conflict remains elusive.

In the past several years, the Israeli government has engaged in various attempts to forge mechanisms to regulate the third type of property claims that arise from the conflict: concerning the rights of Palestinian owners to their property in the West Bank on which Jewish settlements have been built.

Hague Regulation no. 46 forbids the confiscation of private property by an occupying power. ${ }^{95}$ However, the Israeli government has claimed, and the Supreme Court of Israel has recognized, that the military commander in the occupied territories has the authority to take Palestinian private property in the occupied territories for public purposes, in certain circumstances, based on Jordanian law applicable in the West Bank..$^{96}$ The exercise of such authority

$93 I d$. at 48 (with respect to Jewish property seized by the Jordanian Custodian).

94 For a detailed overview of the history of the conflict and its impact on private property, see Benvenisti \& Zamir, supra note 9, at 296-317.

95 Convention (IV) Respecting the Laws and Customs of War on Land and its Annex: Regulations Concerning the Laws and Customs of War on Land regulation 46, The Hague, Oct. 18, 1907.

96 Professional Team for the Formation of Framework Regularizing Construction Area Judea \& Samaria, Final Report 31-32 (2018) (in Hebrew) (written by Haya Zandberg) [hereinafter: Zandberg Report]; HCJ 393/82 Iskan v. Commander 
is permitted when the taking of the private property is necessary to further the rights and wellbeing of the protected population. ${ }^{97}$

Recently, however, in its decision in the case of Ziada, the Court has commented that the Jewish settlers, too, are part of the territories' civilian (albeit not "protected") population, and the military commander of the area is therefore also obligated to protect and advance their welfare, in addition to that of the Palestinian population..$^{98}$ It seems to follow from this interpretive move that Jewish settlers are included in the public whose good may be weighed when determining property claims with respect to properties in the West Bank. Furthermore, if this is the case, Israel, as the representative of the settlers, may have a claim to authoritatively decide on property rights conflicts. In other words, this interpretation gives rise to a claim that the two criteria of inclusion and representation are fulfilled by Israel and it may consequently legitimately decide on private property claims in the West Bank. However, we argue here, this does not solve the issue regarding Israel's fulfillment of these two criteria with respect to the Palestinian population in the West Bank.

Israel's 2017 enactment of the Law for the Regularization of Settlement in Judea and Samaria, 5777-2017, echoes Israel's claim to authoritatively decide private property conflicts in the West Bank. ${ }^{99}$ This law aims to resolve property claims of Palestinians with respect to lands they own but on which settlements have been built. It applies to settlements that had been built "in good faith" or "with the consent of the State." The Law determines that where such property has no owner, it shall be deemed Government Property and assigned to the IDF Custodian. Where there is an owner, the IDF authorities shall take the property's use and possession rights and assign them within 60 days to the use of the settlement. The taking of use and possession rights

of the IDF in the Area of Judea and Samaria 37(4) PD 785 (1983); HCJ 794/17 Ziada v. Commander of IDF Forces in the West Bank (Oct. 31, 2017), Nevo Legal Database (by subscription, in Hebrew) (Isr.).

97 Iskan v. Commander of the IDF, supra note 96, at 808.

98 Ziada v. Commander of IDF Forces, supra note 96, at 9 26. But see ACJ 9367/17 Ziada v. Commander of IDF Forces in the West Bank (May 30, 2018), Nevo Legal Database (by subscription, in Hebrew) (Isr.) (denying a request for renewed consideration of the Ziada decision, since the determination regarding expropriation done for the benefit of Jewish settlers alone, which contradicts the Court's longstanding jurisprudence on the matter, is done in obiter and does not establish legal precedent). While this was an explicit reference, an implicit reference to the Jewish settlers as part of the population entitled to the military government's protection appeared already in 1972 in HCJ 256/72 Electricity Co. for the District of Jerusalem v. Minister of Defense, 27(1) PD 124, 138 (1972).

99 Law for the Regularization of Settlement in Judea and Samaria, supra note 11. 
shall remain in force pending political resolution of the status of the area and settlements therein. The owner whose rights were taken is entitled to monetary compensation or alternative lands. ${ }^{100}$ The Law was challenged before the Supreme Court, which has recently decided to strike it down. ${ }^{101}$

Despite retaining in the Regularization Law Israel's formal commitment to deferring ultimate settlement of property claims to international negotiations, this Law would have the consequence of entrenching the hold of current residents and undermining the ultimate ability of original owners to repossess their property. The Law does not meet the preconditions required to authoritatively regulate the property rights of Palestinian owners in the West Bank: these owners are not included in Israel's political community, nor represented by its government. First, as the Supreme Court has held, the Regularization Law promotes the public good of only one public: its own. ${ }^{102}$ Notwithstanding the Supreme Court's attempt in Ziada to present both the Palestinian protected population and the settlers as similarly situated members of a local community, and despite the formal obligation of the occupying power to consider the welfare of the occupied population, ${ }^{103}$ there is no indication that the interests of the Palestinian owners or the Palestinian community's public good are given sufficient attention in determining how property rights and other goods are allocated. ${ }^{104}$ Moreover, the Palestinian owners in the West Bank do not stand to benefit from the public good derived from the taking of their property by Israel or from other similar takings in the past, present or future: these are one-sided takings - Palestinian land given to Jewish settlers, never vice-versa, and the dispossessed Palestinian owners would not benefit from the thriving

$100 \mathrm{Id}$. at art. 3, 5, 8. As art. 8 stipulates, once an owner's use and possession rights are taken, he will be entitled to choose between receiving compensation at a rate of $125 \%$ of the land's appropriate value as determined by an evaluation committee; or, when possible, to an alternative land.

101 HCJ 1308/17 Silwad, supra note 12.

$102 \mathrm{Id}$. at $\uparrow$ ๆ $74,79$.

103 Hague Regulations, supra note 95, arts. 43, 46; Convention (IV) relative to the Protection of Civilian Persons in Time of War, Geneva, 12 August 1949, 75 U.N.T.S. 287, art. 53. The protected status of the Palestinian population and its private property were central to the Supreme Court's decision to strike down the Regularization Law, HCJ 1308/17 Silwad, supra note 12, see, e.g., at q⿴ 70, 79. See also, Ronit Levine-Schnur, Covert: On Market Overt in Real Estate Property in Judea and Samaria [Lelo Takana: Al Takanat HaShuk BeMekarke'in BeYehuda VeShomron], 50 Mishpatim (forthcoming 2020) (in Hebrew).

104 On the importance of representing disempowered groups in peace negotiations, see Saliternik, supra note 7. 
settlers' ecosystem from which they are excluded. ${ }^{105}$ The one-sided benefit derived from the Regularization Law expropriations was key in the Supreme Court's decision to strike it down, noting that the Law allowed forced takings from one population in order to generate public good that another population is set to enjoy exclusively. ${ }^{106}$ The court did not address, however, the additional criterion that we have suggested: the condition of representation. Palestinians are not part of the political community represented by the State of Israel. They are not represented in its political bodies (and obviously not in the military administration of the area) and they are unable to affect decision-making by Israel that impacts their lives. ${ }^{107}$ Israel's Regularization Law therefore fails on both accounts.

The Zandberg Report, commissioned in 2016 by the Minister of Justice Ayelet Shaked to propose solutions regularizing takings for settlements in the West Bank, makes several claims in support of the military administration's or Israel's authority to unilaterally resolve private property conflicts in the West Bank. One key line of argument in the report underscores the possibility of distinguishing the question of Israel's commission of an international wrongful act from the question of the remedy for that breach. In other words, it suggests separating the discussion of primary and secondary rights. In making this claim, the report relies particularly on the ECtHR's separation of issue of the legality of the occupation in Northern Cyprus from the legitimacy of its property claims commission. ${ }^{108}$ Following this line of argument, the report suggests that one might apply the pragmatic approach introduced above, and submits that endeavoring to settle private property claims in the aftermath of conflict may be justified for the benefit of the local population, even if done unilaterally or with a view to settle only some of the claims that arise. Particularly, the report opines that even if Israel had breached the Fourth Geneva Convention's prohibitions on population transfer and on taking private property of protected persons, the remedy should entail compensation rather than regaining possession of their lands: it is a "win-win situation", the report argues. ${ }^{109}$

105 Eyal Weitzman, Hollow Land: Israel's Architecture of Occupation (2007).

106 HCJ 1308/17 Silwad, supra note 12, at 9甲 74, 79.

107 See, e.g., HCJ 5667/11 Dirat-Rafiya Villiage Council v. Minister of Defense (June 9, 2015), Nevo Legal Database (by subscription, in Hebrew) (Isr.) (denying the petition of Palestinians who challenged the zoning authorization regime applicable in the West Bank for failing to offer them a significant opportunity to participate in planning processes).

108 Zandberg Report, supra note 96, at 150-52.

109 Id. at 137. 
The report further assesses "with great certainty" that in most cases, individual settlers who obtained their rights to reside in Palestinian-owned property from Israeli authorities have done so as good faith purchasers and therefore they have a legitimate expectation to enjoy those rights regardless of any adverse claims. ${ }^{110}$ While the report does not refer directly to international standards for protecting human rights, it seems to invoke the considerations that motivated contemporary human rights law to endorse the legitimate expectations of current residents as protected by both individual and collective human rights, along the lines of Waldron's supersession thesis.

However, this line of argument ignores the institutional aspect that we have emphasized thus far: the pragmatic approach of separating the illegality of the regime from its consequences - as elucidated by the ICJ in the context of Namibia and by the ECtHR concerning Cyprus - was promoted by a third party, a court which was independent of the occupying power and credibly sought to protect the interests of those harmed by illegality. In Namibia, the ICJ sought to protect the citizens of Namibia, namely those already harmed by the illegal occupation of South Africa, and to prevent the further unsettling of their lives that would be expected if the effectiveness of basic state administrative functions such as population registry was revoked. ${ }^{111}$ When applied to the occupied Palestinian territories, this rationale should work in the opposite direction than the one suggested by the Zandberg Report, because as stated above, current regularization attempts by Israel are advanced not for the benefit of the protected Palestinian population, but for the benefit of settlers.

Moreover, in the West Bank, the efforts by Jewish settlers to appropriate more property for expanding existing settlements or establishing new ones persist relentlessly. This distinguishes the situation of taken Palestinian property from the Cyprus precedent. Unlike the case of Cyprus, the threat of continuous taking of Palestinian property is palpable. Although past and present Israeli legislation formally recognizes the property claims of dispossessed owners and acknowledges de jure that rights ought to be finally resolved in the aftermath of conflict, the practice of Israel on the ground has made it hard to view the arrangement as temporary. ${ }^{112}$ Therefore, the mechanisms that Israel

110 Id. at $143-44$.

$111 C f$. Ronen, supra note 1, at 98-100 (identifying the Namibia exception beneficiaries as including "any person affected by the illegal regime, including people outside its territory but subject to its control," $i d$. at 98).

112 Talia Sasson, Report Concerning Unauthorized Outposts 44 (2005):

It therefore appears that the breaking of law has become institutionalized and institutional. We are not dealing with a criminal or a group of criminals operating contrary to the law. The picture that is revealed to the observer is of a blunt violation of the law by certain state authorities, public authorities, 
seeks to adopt in this context have a clear air of ex ante approval of further dispossession of Palestinians, now with a formal, legislative stamp of approval.

In conclusion, Israel's attempt to unilaterally settle the property claims of Palestinians in the West Bank is flawed because it does not advance the public good of the Palestinians, which would mitigate the harm of private property deprivation. It is flawed also because Israel itself cannot - and does not claim to - represent the Palestinians, and it has not allowed their representatives to participate in designing the mechanism for resolving claims.

\section{Conclusion}

No system of law-domestic or international - that protects the right to property grants owners absolute title. Under international human rights law, property may be limited or taken, if doing so is warranted for the public good. A relevant public authority has the discretion to balance competing interests and decide on such takings, provided that two necessary (but not sufficient) conditions are met: (1) that the dispossessed owner is included in the public whose good is augmented by the taking or by other takings in the past, present or future, and (2) that she is represented by the authority making the determination.

In post-conflict settlement of private property claims, these conditions must be met with respect to owners whose property claims are resolved. These owners must be part of the communities represented by the negotiating governments, and they must stand to benefit from the overall augmented public good of these communities. Against this background, unilateral attempts to settle private property claims prior to the peaceful resolution of the armed conflict raise concerns, since they entail the decision of a government on the rights of individuals who are not part of its political community and are not represented by it.

local authorities in the Area of Judea and Samaria and settlers, all the while upholding the false appearance of an orderly institutional system operating according to law.

Law for the Regularization of Settlement in Judea and Samaria, 5777-2017, 2604 SH 410 (Isr.), Art. 2 defines "Consent of the State" as "explicitly or implicitly, in advance or after the fact, including assistance in providing infrastructure, providing incentives, planning, publishing of publications meant to encourage building or developing or making contributions in cash or in kind". 
